\begin{tabular}{ll}
\hline \hline MINING AND METALLURGY INSTITUTE BOR & ISSN: 2334-8836 (Štampano izdanje) \\
UDK: 622 & ISSN: 2406-1395 (Online) \\
\hline \hline
\end{tabular}

\author{
Zoran Katanić, Jelena Katanić $^{* *}$
}

\title{
VALORIZATION OF THE MINERAL AND \\ THERMAL WATER OF KOSOVO AND METOHIJA IN A FUNCTION OF HEALTH TOURISM
}

\begin{abstract}
Valorization of the mineral and thermal water of Kosovo and Metohija in a function of health tourism is an important issue for recognizing the Autonomous Province of Kosovo and Metohija (AP KiM) as a significant tourist destination. Valorization of the mineral and thermal water in the territory former SFRY, to which Kosovo and Metohija belonged was largely based on the applicable legal regulations in the observed time period. The economic valorization of mineral and thermal water was generally lacking. The situation has changed significantly in recent years in the area of health tourism, which needs yet to get its portion of the budget while competing with the other social areas. Therefore, health tourism itself should become the very source of profit. Valorization of the mineral and thermal mineral water of Kosovo and Metohija should be based on the world criteria that contribute both to the economic development and reconciliation process. Furthermore, a part of research in the study paper, the special emphasis has been placed on the identification of sources of thermal and mineral water as a natural attraction in Kosovo and Metohija, elements of tourist valorization and the importance of mineral and thermo mineral water for development the tourist economy in Kosovo and Metohija.

Keywords: mineral and thermo-mineral water, spas, valorization, tourist product, health tourism
\end{abstract}

\section{SUBJECT OF RESEARCH}

The chosen research problem is a result of years of analytical work in the fields of economics, hydrogeology and balneology. As well as the identification of thermal mineral water in Kosovo and Metohija, analysis and their definition as a tourist potential and attractiveness and creating opportunities for their tourist presentation and valorization. The problem of research in this study dealt with the question: How to create the modern tools that will valorize the mineral and thermo mineral watering a function of health tourism in a way that will contribute to the promotion of health tourism as an industry branch and overall economic and social

progress of population, considering numerous current problems in the area Kosovo and Metohija after years of conflict?

\section{GENERAL HYPOTHESIS}

The mineral and thermo-mineral water of Kosovo and Metohija in a function of health tourism and as a tourist product are individually and as a whole economically congruent. The study is based on a hypothesis that the valorization of mineral and thermo mineral water of Kosovo and Metohija contributes to raising the awareness of all interested parties about a need to create the tools necessary for their

\footnotetext{
*College of Professional Medical Studies “Medika”, Belgrade, Serbia, zorankatanic@yahoo.com

** College of Modern Business, Belgrade, Serbia, e-mail: jelenakatanic2010@gmail.com
} 


\section{METHODOLOGY}

recognition as an attractive, contemporary and competitive tourism product. This hypothesis as such is proven by the authentic statements.

\section{OBJECTIVE}

Scientific objective of research is to gain a knowledge at the level of scientific description and classification with the elements of scientific explanation. A special aspect of research is aimed at diagnosing the basic problems evident in the field of health tourism development in Kosovo and Metohija. The scientific objective is reflected in the initial exploration of application conditions and adaptation the general economic principles important in the field of tourism management in a context of specific and turbulent relations between people regarding the unresolved political issues. Moreover, it is necessary to present scientifically the based evidence on complementaty the mineral and thermo mineral valorization with function of tourist product and tourist offer. The practical aim of research is to define and regulate the activities and measures to be taken in order to achieve an adequate level of development the health tourism as an important segment in a path of society development. In order to achieve this objective, it is necessary to investigate objectively, clarify and properly present all important in the field of health tourism development in relation to the mineral and thermo mineral water in the area of Kosovo and Metohija.

The practical value of research is reflected in a proposal of certain practical solutions for development the health tourism, in a way that enables those solutions to be adapted and incorporated while respecting the real needs and opportunities in a holistic approach to the development of health tourism.
Considering that the study is of an interdisciplinary character, a characteristic, generally accepted methodology in the field of social sciences has been used. The authors of the study believe that there is no absolutely correct methodology for the field of social research, but that it presents different ways of viewing the world, measuring and understanding the social reality. The selection of research methods was carefully performed in accordance with their own experience and research problem.

The scientific and logistical methods used were: synthesis and deduction analysis, induction and content analysis. Out of the general scientific methods, the statistical method and comparative method were used. The collecting data survey was conducted on the basis of pre-prepared and formulated questions.

\section{INTRODUCTION}

Valorization has become a priority issue under current circumstances at every level, starting from the global to local. The developed countries make great efforts to valorize the mineral and thermo mineral water as it contributes to preservation of its essential value, but at the same time emphasizes the increasing importance of health tourism. Mineral water should prove their worth in a way that is understandable to the decision makers. Value means both the preferences and desire of someone for a specific service at a specific point of time.

Movable goods have a market in which their price is defined according to supply and demand, while the real estate does not have a market in which its economic value can be determined. The total economic value consists of the "use value", or in the other words the "passive use value" of resource. The value of non- 
use (existence value) has emerged as a result of numerous debates in the scientific community. [1] Back in 1967, in his article in the American Economic Review, John Krutilla proposed a compromise that initiated the desired changes. He emphasized that the economic science should adopt a concept that has become known as the "existence of value". The concept has been accepted and consequently many economists have made or are making efforts to express the value in currency. [2]

It is necessary to initiate a process of economic value assessment in a timely manner that can be compared with the investment cost of preservation of each good individually. [3]

\section{ECONOMIC VALORIZATION TECHNIQUES}

Specific valorization techniques are required for determination the total economic value of mineral and thermo mineral water. In such cases, it is impossible to use the Cost Benefit Analysis (CBA), which has a significant place in the applied economy. Bedate points out the importance of three methods: hedonic pricing, travel costs and conditional valuation. [4]

There are two groups of techniques that can be applied in the valorization of mineral and thermo mineral water: techniques of discovered preferences, where preferences are derived from information collected in the real market; stated preference techniques used when information and data are collected directly from consumers through the use of various questionnaires; techniques of revealed preferences when the value of goods is derived from data on realized transactions in the market; hedonic pricing refers to the analysis of those markets where certain activities have an impact on price; [5] method of travel cost is based on the fact that the value of resources is viewed through the cost of travel and stay in certain properties [6].

\section{IDENTIFICATION OF THE THERMOMINERAL WATER SOURCES AS THE NATURAL ATTRACTIONS IN KOSOVO AND METOHIJA}

The area of Kosovo and Metohija is characterized by a very complex geological structure and numerous thermo mineral water and springs where the famous spas were built: Pećka Ilidža near Peć, Klokot Banja near Vitina, Banjska (Rajska Banja) near Zvečan, Kmetovska near Gnjilane, Ugljarska near Gračanica, and Žitinje near Klokot Spa. There are also so-called the "wild spa" near Kaljare with a temperature of $28.6^{\circ} \mathrm{C}$, spa Vuča near Leposavić, socalled Slatina thermo-mineral source of salt water near the village of Slatina, and Kisela spa is near Podujevo. The Smrdan Spa located at the mouth of Sitnica into the Ibar River, as well as Glamska Spa near Novi Brdo, Gatnjanska Spa near Uroševac, Dečanski Kiseljak located in Dečani, should be included in this group. The spas are ideal places to meet the human recreational needs. [7]

Pećka Banja - Spa (Ilidža) near Peć is the most famous spa in Kosovo and Metohija. There is a number of thermo mineral watering Banja and its immediate vicinity with water temperatures ranging $12-47.5^{\circ} \mathrm{C}$. [8]

Klokot Banja is located in the Binačka Morava valley in place Klokot. Thermomineral water of Klokot Banja belong to cold, hypo and homeothermal $\left(18-37^{\circ} \mathrm{C}\right)$ containing metasilicic acid (up to $174 \mathrm{mg} / \mathrm{l}$ ), metabolic acid (up to $53 \mathrm{mg} / \mathrm{l}$ ), lithium $(1.06 \mathrm{mg} / \mathrm{l})$, fluorine $(2.4 \mathrm{mg} / \mathrm{l})$, iron (up to $15 \mathrm{mg} / \mathrm{l})$, radium, strontium, etc. Mineral water from the spring in Klokot Banja belongs to alkaline water in terms of mineral composition. Cold mineral water from one of the source contains carbon dioxide, and is used for drinking and bottling. 
Banjska (Rajska spa) is located on the southeastern slopes of Mount Rogozna $(1504 \mathrm{~m})$, at $533 \mathrm{~m}$ above sea level. The water temperature at the springs is: $40.1^{\circ} \mathrm{C}, 58.1^{\circ} \mathrm{C}, 28.3^{\circ} \mathrm{C}, 38.4^{\circ} \mathrm{C}$. [10]

Kmetovska Banja near Gnjilane has seven springs of thermo mineral and mineral water. The juvenile water of Kiseli source (acid source) giving 1 liter/sec was analyzed algological and its temperature is $27^{\circ} \mathrm{C}$. [8]

\section{ELEMENTS OF THE TOURIST VALORIZATION OF THE SPAS IN KOSOVO AND METOHIJA}

The geographical position is a key element of the tourist valorization of the spa. In doing so, it is necessary to observe the geographical location of the spa according to the major communication routes, attractive tourist environment and populated areas.

The Kosovo Metohija spas have the most favorable position in terms of communication routes. Also, spas in this area have a favorable position towards urban settlements as the emission areas and towards the attractive tourist facilities, i.e. monuments as the tourist motives (Pećka Banja (Spa) is close to the Monastery of the Patriarchate of Peć and Rugova Gorge; Banjska (Rajska Spa) near Zvečan is in the immediate vicinity of Banjska Monastery, etc. which can be successfully integrated with the tourist offer of spas.

Namely, a large number of Kosovo Metohija spas are located in the area of mountains that form an important natural motivational basis for the tourism development (Šara Mountains, Prokletije, Rogozna, and Kopaonik). Based on the overall analysis of the tourist geographic location, the spas of Kosovo and Metohija are divided into three groups:

- First group - Banjska (Rajska banja) in the immediate vicinity of the major communication routes
- Second group - Pećka and Klokot Spas located in the vicinity of other tourist motives

- Third group - other spas

\section{THE IMPORTANCE OF THERMO MINERAL WATERFOR DEVELOPMENT THE TOURIST ECONOMY IN KOSOVO AND METOHIJA}

Each country has characteristics that make it different and typical, and tourism is actually based on that diversity. [11] One of the basic balneological features of thermo mineral water is their healing function.

Thermal mineral water sources represent the basis of health tourism development in Kosovo and Metohija. The importance of thermo mineral water is multifunctional regarding the development of health tourism, because in combination with balnotherapy as a special therapeutic discipline and wellness programs, it influences the preservation of population health, recreation, prevention, treatment and rehabilitation. Sources of healing water, with the exploitation of peloids, the use of gases in balneological treatment offer a perspective of development the spa tourism.

The oldest form of tourism is health, but it is not the only one. The spas become city centers, destinations for picnics, excursion, cultural-sport events, cultural manifestation and congress tourism, as well as the tourism for the third age and transit tourism. [12]

Banjska (Rajska Spa) has springs of thermal and healing water that have been irreversibly flowing into the Ibar River for decades. Its utilization is almost negligible. Instead of being wasted, this natural gift could be used to heat up the settlements of Banjska and Zvecan. Geothermal or hydrothermal water is a unique source of renewable energy because its use in healing requires relatively simple and inexpensive technology. 
Many countries use the energy of geothermal sources to generate the electricity. The use of geothermal energy and its resources in Kosovo and Metohija is almost negligible in comparison to its potential. The reasons for this situation are unclear, bearing in mind that some sources are the best in the region and that the development of geothermal technology in Europe has advanced. Unfortunately, the use of geothermal water is mainly represented in the spa treatment and for sports and recre- ational purposes. Globally, the geothermal sources are mainly used for space heating, but also for the production of vegetables in greenhouses, in livestock breeding, in various production processes, etc.

\section{RESEARCH RESULTS}

The following tables provide a detailed analysis of data collected on the potential of Kosovo and Metohija for development the spa and health tourism.

Table 1 Number of respondents and percentage per gender

\begin{tabular}{ccc}
\hline Gender & Number of respondents & Percentage \\
\hline Male & 39 & $52 \%$ \\
Female & 36 & $48 \%$ \\
Total & 75 & \\
\hline
\end{tabular}

The survey covered 75 respondents, women (48\%), broken down by the age out of which 39 were men $(52 \%)$ and 36 group:

Table 2 Number of respondents and percentage per age

\begin{tabular}{ccc}
\hline Age & Number of respondents & Percentage \\
\hline Up to 25 & $/$ & $/$ \\
$26-35$ & 14 & $19.5 \%$ \\
$36-44$ & 22 & $30.6 \%$ \\
$45-54$ & 25 & $33.3 \%$ \\
55 and more & 14 & $18.6 \%$ \\
\hline
\end{tabular}

Survey covered the respondents of all levels of education:

Table 3 Number of respondents and percentage per level of education

\begin{tabular}{lcc}
\hline Level of education & Number of respondents & Percentage \\
\hline Primary school & 1 & $1.4 \%$ \\
High school & 26 & $36.1 \%$ \\
Junior College & 9 & $12.5 \%$ \\
Faculty & 29 & $40.3 \%$ \\
Master & 5 & $7 \%$ \\
Master & $/$ & $/$ \\
PHD & 2 & $2.7 \%$ \\
\hline
\end{tabular}


The majority of respondents have higher education in order to provide more meaningful answers to the survey. Considering that the cultural tourists are persons with relatively higher education and above average incomes, this market segment will be increasingly significant from the point of view of economic impact [13]

The next question was whether Kosovo and Metohija had an adequate potential for development the health tourism, and a large number of respondents, $86.7 \%$, thought it had one.

Table 4 Number of respondents and percentage of question asked

\begin{tabular}{|l|c|c|}
\hline \multicolumn{1}{|c|}{ Answer } & Number of respondents & Percentage \\
\hline Yes & 65 & $86.7 \%$ \\
\hline No & 6 & $8 \%$ \\
\hline I do not know & 4 & $5.3 \%$ \\
\hline
\end{tabular}

When a large number of respondents was asked which of the following elements are considered as important for the tourism offer of Kosovo and Metohija, they made up their mind for the sacral sites of the
Serbian Orthodox Church 24.3\%, Winter Ski Center in Brezovica 16.9\%, Gazimestan Memorial Park 12.1\%, Gazivode Lake $13.7 \%$, Rajska Banja (Spa) in Banjska 7.9\%

Table 5 Number of answers given and percentage of question asked

\begin{tabular}{lcc}
\hline \multicolumn{1}{c}{ Offered elements } & Number of answers & Percentage \\
\hline Sacral sites & 46 & $24.3 \%$ \\
Winter Center Brezovica & 32 & $16.9 \%$ \\
$\begin{array}{l}\text { Crkvina, old cemeteries } \\
\text { and inscriptions }\end{array}$ & 6 & $3.1 \%$ \\
Memorial sites & 4 & $2.1 \%$ \\
Rural tourism & 16 & $8.4 \%$ \\
Memorial park Gazimestan & 23 & $12.1 \%$ \\
Lake Gazivode & 26 & $13.7 \%$ \\
Tradition, folklore and & 11 & $5.8 \%$ \\
gastronomy & 15 & $7.9 \%$ \\
Rajska banja in Banjska & 9 & $4.7 \%$ \\
Natural sites & 1 & $0.5 \%$ \\
Old villas & 1 & $0.5 \%$ \\
\hline others & & \\
\hline
\end{tabular}


Table 6 Number of answers given and percentage of question asked

\begin{tabular}{lcc}
\hline \multicolumn{1}{c}{$\begin{array}{c}\text { Offered elements for enhancement of } \\
\text { the cultural tourism offer }\end{array}$} & $\begin{array}{c}\text { Number of giver } \\
\text { answers }\end{array}$ & Percentage \\
\hline $\begin{array}{l}\text { Health and spa tourism } \\
\text { Organization of gastronomic events }\end{array}$ & 79 & $23.2 \%$ \\
$\begin{array}{l}\text { Creation of cultural routes } \\
\text { Linking the cultural tourism offer of Kosovo and } \\
\begin{array}{l}\text { Metohija with the offer of the surrounding countries, } \\
\text { which have rich cultural and historical heritage }\end{array}\end{array}$ & 13 & $7.1 \%$ \\
$\begin{array}{l}\text { Organization of greater number of events } \\
\text { throughout the year }\end{array}$ & 19 & $11.2 \%$ \\
$\begin{array}{l}\text { Transit tourism } \\
\begin{array}{l}\text { Collaboration of tourism providers and cultural } \\
\text { institutions aimed at introduction of innovations into } \\
\text { the existing cultural tourism offer }\end{array}\end{array}$ & 11 & $11.2 \%$ \\
$\begin{array}{l}\text { Legal regulation on the preservation, protection of } \\
\text { sites of cultural and historical heritage }\end{array}$ & 12 & $2.9 \%$ \\
$\begin{array}{l}\text { Complementing the cultural tourism offer with the } \\
\text { additional amenities such as active holidays, sports } \\
\text { and recreation, spa and wellness services }\end{array}$ & $9.5 \%$ \\
\hline \begin{tabular}{l} 
Monastery tours \\
\hline
\end{tabular} & 32 & $7.1 \%$ \\
\hline
\end{tabular}

According to the respondents, the most significant offered elements that would contribute to the improvement of tourism offer of Kosovo and Metohija are the health and spa tourism with $23.2 \%$, monastery tours with $19 \%$ of the given answers.

\section{CONCLUSION}

This study has been based on the hypothesis that the valorization of mineral and thermal waters of Kosovo and Metohija in the function of health tourism contributes to raising awareness of all interested parties about the need to create tools (models) necessary for their recognition as an attractive, modern and competitive tourism product. This hypothesis is proven by the realization of research sub problems. The basic hypothesis indicated the need for valorization process to be envisioned and created in such a way as to avoid the popularization of mineral and thermo mineral water individually due to ethnic groups living in the territory of Kosovo and Metohija. Valorization should be designed in a way that takes into account numerous indicators. The experience of developed countries in valorization is of imeasurable importance in this process. This process will not be easy or straightforward due to many undesirable circumstances, of which, above all, are the political instability and problem of securing the necessary financial resources provided for this purpose. The valorization process is an interdisciplinary work. This important task should be done by a group of experts of various profiles. The valorization process should be carried out with a particular sensitivity in the territory of Kosovo and Metohija given the centuries-old conflict between Serbs and Albanians. Expectations that the valorizetion process can be done in the short term are unrealistic.

The conclusion is that the valorization process is a continuous, dynamic process and that it can never be completed in its entirety. The survey has shown the aspirations of respondents to visit a tourist destinations that have spiritual contents, natural beauty. The results of research indicate that a systematic approach to organizing the tourist offer and supply of additional tourist facilities is needed in order to provide tourists with a high quality experience during their stay in Kosovo and Metohija. It should 
be remembered that the new tourism products are aimed to reduce the marketing costs. Modern technologies and improvement of customer service in this process are indispensable.

Health tourism for the development of Kosovo and Metohija is very important. In a period of stagnation, significant economic crisis and certain disappointment of population with a high unemployment rate and poor economic situation, every step aimed at offering a greater employment and better living and working conditions means progress towards the sustainable development of society. The valorization of mineral and thermo mineral water is one of the most important tasks on this path that leads from the past to the future that can and should be a significantly different.

\section{REFERENCES}

[1] Nelson R. H. (1997). Does "Existence Value" Exist?: Environmental Economics Enriches on Religion. Independent Review, 1(4), 499+. Retrieved from http://go.galegroup.com/ps/i.do?p $=\mathrm{AONE} \& \mathrm{sw}=\mathrm{w} \& \mathrm{u}=\mathrm{ussd} \& \mathrm{v}=2.1 \& \mathrm{it}=\mathrm{r}$ \&id=GALE\%7CA19918181\&asid=b3 79f1d2b22f306b7029b99707ca8a82

[2] M. Robert, and R. Carson. (1989), Using Surveys to Value Public Goods: The Contingent Valuation Method. Washington, D.C.: Resources for the Future. Portney, Paul R. (1994). The Contingent Valuation Debate: Why Economists Should Care. Journal of Economic Perspectives 8 (Fall): 3-17.

[3] Katanić Z. Valorization of Cultural Values of Kosovo and Metohija in Function of Tourist Offer, Doctoral Dissertation, Singidunum University, Belgrade, 2017, p.129

[4] Bedate A, Herrero L.C., Sanz J.A. (2004), Economic Valorization of the Cultural Heritage: Application to Four Case Studies in Spain. Journal of Cultural Heritage, Volume 5, Issue 1, pp. 101-111.

[5] Rosen S. (1974), Hedonic Prices and Implicit Markets: Production Diffe- rentiation in Pure Competition. Journal of Political Economy 82: 34-55.

[6] Eftec (2005) Valuation of the Historic Environment: The Scope for Using Results of Valuation Studies in the Appraisal and Assessment of HeritageRelated Projects and Programs: Executive Summary London:

[7] Jovičić D., (2008), State and Prospects for the Development of Spa Tourism in Serbia, Bulletin of the Serbian Geographical Society, Volume LXXXVIII-No. 4, Belgrade, page 3-18

[8] Cvijan M., (1987), Algological Typification of Thermo Mineral Water in SR Serbia, Bulletin of the Institute of Botany and Botanical Gardens, University of Belgrade, Volume XXI, Belgrade, page 72

[9] Maćejka M., Đorđević T., Klokot Banja, (2012-2013), Globus 37-38 Journal of Methodological and Didactic Issues in Geography, Belgrade, page 41

[10] Milentijević G., Nedeljković B., (2010), Thermal Mineral Water of Banjska, Potentiality, Quality, Possibility of Use, Mining Works, No. 1, Committee for Underground Mining, Mining and Metallurgy Institute Bor, Bor, page 151

[11] Stojanović T., Čerović S., (2008), Importance of Gastronomic Offer for the Development of Rural Tourism in Serbia, Proceedings, Faculty of Geography, University of Belgrade, Vol. LVI, Belgrade, page 165

[12] Momirović D., (2007), ThermoMineral Springs in the Function of Health Tourism Development in the Timok Region, Timok Medical Journal, Journal of the Branch of the Serbian Medical Association Zajecar, Volume 32, No. 4, page205-215

[13] Hadžić O., Stojaković G., HermanMilinković K., Vanić T., Ivanović I., Cultural Tourism, Faculty of Natural Science and Matematics, Department of Geography, Tourism and Hotel Management, University of Novi Sad, Novi Sad, 2005 